\title{
Dyskurs edukacyjny w ujęciu procesualno-kognitywnym ${ }^{\star}$
}

\section{KEYWORDS}

discourse, educational discourse, formalized educational discourse, ideology, critical discourse analysis, rhetorical discourse analysis, topoi

\begin{abstract}
Rypel Agnieszka, Dyskurs edukacyjny w ujęciu procesualno-kognitywnym [Educational discourse in the processual-cognitive perspective]. Kultura - Społeczeństwo - Edukacja nr 2(12) 2017, Poznań 2017, pp. 9-35, Adam Mickiewicz University Press. ISSN 2300-0422. DOI 10.14746/kse.2017.12.1.
\end{abstract}

The paper attempts at presenting diversity in discourse research and defining educational discourse in its new cognitive-procesual aspect. The analysis is concentrated on formalized educational discourse undergoing ideological influences through mass, public and government supervised education. For the detailed discussion multiperspective method including critical and rhetorical analysis has been proposed acknowledging the separateness of makro and discursive strategies together with their topoi in the common ideological - cognitive mean.

\section{Wprowadzenie}

Pojęcie „dyskurs” występuje w paradygmatach wielu nauk humanistycznych i społecznych. Jego pole semantyczne stale się rozszerza, a znaczenie staje się coraz bardziej rozmyte. Tradycyjnie używa się go na określenie interakcji czy też zdarzeń

* Artykuł prezentuje koncepcję dyskursu edukacyjnego oraz metody jego badania przedstawione w książce: A. Rypel, Ideologiczny wymiar dyskursu edukacyjnego. Na przykładzie podręczników języka polskiego z lat 1918-2010, Bydgoszcz 2012. 
komunikacyjnych (jednostkowych lub długotrwałych), które mają na celu przekazanie myśli i wpłynięcie na odbiorcę poprzez odpowiednio dobrane argumenty. Obecnie służy również do charakteryzowania języka używanego w rozmaitych praktykach społecznych (na przykład dyskurs polityczny, naukowy, edukacyjny), w odniesieniu do zbiorowości (na przykład dyskurs prawników, lekarzy, użytkowników Facebooka), instytucji (na przykład dyskurs Unii Europejskiej, dyskurs polskiego Kościoła) lub wyłącznie jednej osoby (na przykład dyskurs Martina Luthera Kinga, dyskurs Marine Le Pen), a także do konkretnej sytuacji komunikacyjnej (na przykład dyskurs lekcyjny, dyskurs wizyty u lekarza). Dyskursem nazywa się także zespół wartości, koncepcji i poglądów (na przykład dyskurs ekologiczny, neoliberalny, prawicowy) (por. Lisowska-Magdziarz, 2006: 13-14). Wymienione zakresy znaczeniowe mogą się łączyć, krzyżować lub wzajemnie dopełniać, a zatem każdy, kto zamierza zająć się badaniem jakiegokolwiek aspektu dyskursu, musi zmierzyć się z metodologicznymi trudnościami wynikającymi z tak wielu sposobów jego rozumienia ${ }^{1}$.

Teorie opisujące dyskurs łączy wspólny punkt wyjścia - interaktywna perspektywa spojrzenia na mowę, przyjęta przez Émile’a Benveniste’a (Benveniste, 1966; Dessons, 2006), oraz odniesienia do zaproponowanej przez Paula Ricoeura (Ricoeur, 1989) dyskursywnej koncepcji języka, zgodnie z którą dyskurs traktuje się jako zdarzenie językowe zachodzące w określonym porządku czasowym, wyznaczanym przez następujące po sobie wypowiedzi. $Z$ tej koncepcji wywodzi się także przekonanie, że dyskurs jest zjawiskiem indywidualnym, w którym zawsze ktoś mówi do kogoś, odnosząc się przy tym do zewnętrznych warunków, w których dyskurs się odbywa. Według Ricoeura tylko dyskurs, w przeciwieństwie do języka (parole) - abstrakcyjnego, pozaczasowego i niemającego samodzielnego sensu - może mieć charakter znaczący i przekazywać określone treści (Ricoeur, 1989: 75). Z kolei Michel Foucault, trzeci z wielkich prekursorów dzisiejszych badań nad dyskursem, kieruje uwagę w stronę kontekstu i zachodzących w nim zdarzeń dyskursywnych (wypowiedzi), rozumianych jako sposób istnienia realizacji werbalnej w takiej postaci, w jakiej ona rzeczywiście nastąpiła (Foucault, 1977: 143). Przedmiotem jego badań nie było hermeneutyczne wyjaśnianie znaczeń tych szczegółowych jednostek dyskursu, ale sposób, w jaki owe jednostki istnieją - co to znaczy, że się ujawniły, dlaczego w danym miejscu i czasie zjawiły się właśnie te, a nie

\footnotetext{
${ }^{1}$ Na gruncie samej tylko lingwistyki i lingwodydaktyki wielość opracowań i reprezentowanych w nich podejść obrazuje to skrócone zestawienie: Zawadowski, 1966; Kurcz, 1992; Labocha, 1996a, 1996b; Żydek-Bednarczuk, Zeler, 1996; Grabias 1997; Dąmbska-Prokop, 1997; Duszak, 1998; Gajda, 1999; Kawka, 1999; Witkowska, 2004; Wiśniewska, 2005; Żydek-Bednarczuk, 2005; Grzmil-Tylutki, 2007; Rittel, Rittel, 2015.
} 
inne wypowiedzi związane z konkretnym systemem odniesieniowym (Foucault, 1966: 71). Zdaniem badacza formowanie się wypowiedzi nie zależy jedynie od reguł języka i logiki. Pojęcie dyskursu pozwala postrzegać te jednostki językowe w powiązaniu z odrębnymi regułami, na które składają się między innymi czynniki społeczne, instytucjonalne i światopoglądowe (ideologiczne). To właśnie one wpływają na kształt, przedmiot bądź wybór tematyki wypowiedzi oraz na to, kto i z jakiej pozycji je formułuje.

Wśród pojawiających się na gruncie lingwistyki i nauk społecznych sposobów rozumienia dyskursu wyodrębnić można kilka zasadniczych typów podejść: procesualne, interakcyjne, strategiczne, kognitywne, kulturowe ${ }^{2}$.

Pierwsze z nich - podejście procesualne - koncentruje się na procesach kształtujących zjawiska komunikacyjne. Nawiązuje do zasady implikacji Benveniste’a, zgodnie z którą społeczeństwo tworzy język, ale i równocześnie język tworzy społeczeństwo:

Język rodzi się w tym samym procesie, co społeczeństwo, w wysiłku wytwarzania środków do życia, przekształcania przyrody i mnożenia narzędzi. W tej właśnie kolektywnej pracy i przez tę pracę język się zróżnicowuje, zwiększa swoją produktywność, podobnie jak społeczeństwo różnicuje się poprzez swe działania materialne i intelektualne. (Benveniste, 1980: 32)

W tym samym nurcie myślenia mieści się wspomniany wcześniej sposób badania dyskursu zaproponowany przez Michela Foucaulta oraz rozważania nad związkiem między władzą, wiedzą i dyskursem zawarte w pracach Pierre’a Bourdieu (Bourdieu, Passeron, 1990; Bourdieu, 2005). Na tej podstawie podejście procesualne sprowadzić można do trzech zasadniczych założeń:

1) dyskurs to praktyka formująca przedmioty, o których ów dyskurs mówi;

2) dyskurs obejmuje znaczenia i stosunki społeczne, ustanawiając jednocześnie zarówno podmiotowość, jak i stosunki władzy;

3) dyskursy stanowią mechanizmy strukturyzujące instytucje społeczne, sposób myślenia oraz subiektywne doświadczenia (zob. Foucault, 1977), co oznacza, że poszczególne dyskursy dookreślają się we wzajemnej grze, kształtując w tym procesie rozmaite zjawiska społeczne.

Podejście interakcyjne zainspirowane jest naukami społecznymi (głównie socjologią), które rozpatrują dyskurs w kategorii działań społecznych podejmowanych przez użytkowników języka. Dyskurs to zatem rodzaj „zachowań językowych, których postać zależy od tego, kto mówi, do kogo, w jakiej sytuacji i w jakim

2 Anna Duszak nazywa je modelami teoretycznymi: procesualnym, strategicznym, kognitywnym i interakcyjnym (Duszak, 1998: 118). 
celu" (Grabias, 1997: 264). To komunikacyjne działanie wyznacza typ interakcji, który jest koordynowany przez akty mowy, czyli pojedyncze zdarzenia językowe. Nie są one tożsame z dyskursem - porządkują go, ale też same pod wpływem kontekstu zmieniają lub wewnętrznie różnicują swoje funkcje i znaczenie, na przykład mają charakter jednocześnie dyrektywny (nakłaniają do działania) i ekspresywny (wyrażają stan emocjonalny) bądź też przedstawiają sądy (asercje) i równocześnie są obietnicą, to znaczy wyrażają podjęcie przez mówiącego zobowiązania do działania i odpowiedzialności za nie (komisywy). W związku z tym poszukiwanie reguł dyskursu nie może ograniczać się jedynie do poziomu języka jako systemu semiotycznego rządzącego się własnymi prawami, ale powinno także obejmować poziom zjawisk psychofizycznych oraz poziom zjawisk społecznych.

Podejście interakcyjne ma swoje filozoficzne umocowanie w koncepcji Jürgena Habermasa, wzbogacającej badania nad dyskursem o aspekt etyczny głównie dzięki przyjęciu rozróżnienia między kategoriami „krytyki” i „dyskursu” (Habermas, 2004). „Krytyka” nie zakłada możliwości porozumienia lub wolnej od ograniczeń komunikacji, „dyskurs” zaś opiera się na przeświadczeniu, że racjonalne porozumienie może być uzyskane w kontekście komunikacyjnym wolnym od wewnętrznych i zewnętrznych ograniczeń. Uzyskanie porozumienia musi jednak uwzględniać tak zwane „roszczenia ważności” (czyli roszczenia: zrozumiałości, wiarygodności, prawdziwości i słuszności normatywnej³), dzięki którym sytuacja idealnej komunikacji może być wolna zarówno od wewnętrznych, jak i zewnętrznych form przemocy lub przymusu, zapewniając równość możliwości w sferze uczestnictwa i jednakowej wzajemności w rolach podejmowanych przez uczestników dyskursu. Dochodzenie do porozumienia odbywa się zatem poprzez podnoszenie jednego ze wspomnianych roszczeń ważnościowych - jego krytycznej analizy, w następstwie której roszczenie to zostaje odrzucone bądź zaakceptowane.

Podejście strategiczne zasadza się na założeniu, że społeczność dyskursywna i rodzaj społeczności (wspólnoty) komunikacyjnej są budowane na gruncie wspólnoty ideowo-kulturowej i określonej wizji świata, wybieranej zależnie od zainteresowań i okoliczności. Połączoną w ten sposób grupę charakteryzuje używanie swoistych środków językowych: słów sztandarowych czy słów kluczy, reprodukowanych konstrukcji zdaniowych, na przykład formuł etykietalnych (Gajda, 2001: 8-9). Dyskurs, jako przejaw typowego dla danej kultury sposobu

\footnotetext{
${ }^{3}$ Roszczenie zrozu miałości zakłada, że tylko zrozumiałe akty mowy mają szansę, by uzyskać prawomocność; roszczenie wi arygodności dotyczy zgodności aktów mowy z intencjami mówiącego; roszczenie prawdziwości odwołuje się do przeświadczenia, że tylko odwołanie do dyskurs teoretycznego może zweryfikować lub sfalsyfikować dane stwierdzenia; roszczenie słu s zności normatywnej odwołuje się z kolei do dyskursu praktycznego (Evert, 1993: 141-142).
} 
porozumiewania się, opisywany jest przez normy i strategie stosowane w procesie tworzenia wypowiedzi. Podstawą tych strategii są wzorce społeczne i kulturowe, składające się na normę stosowaną do formułowania tekstu/wypowiedzi o określonych cechach gatunkowych (Labocha, 1996a: 51).

Kluczowym dla tego podejścia jest (rozmaicie konkretyzowane przez poszczególnych badaczy) pojęcie „kompetencji dyskursywnej” (Charaudeau, 2001: 344). Dzięki niej uczestnik komunikacji jest zdolny do rozpoznawania i praktycznego stosowania różnych zabiegów dyskursywnych zależnie od parametrów sytuacyjnych. Oznacza to, że potrafi on tworzyć i interpretować teksty, odwołując się do systemu wartości, intencji i celów odbiorcy oraz przystosowywać jednocześnie własne strategie komunikacyjne do różnorodności i ulotności relacji interpersonalnych (Charaudeau, 2001: 344).

Podejście kognitywne bazuje na przekonaniu, że to „nie tyle dyskurs ma znaczenie, co raczej znaczenie jest czymś przypisywanym dyskursowi” (Van Dijk, 2001: 17), a porozumiewanie się stanowi dynamiczny i otwarty proces poddawany ciągłym reinterpretacjom. Według reprezentującego to podejście Gilles’a Fauconniera język jest jedynie powierzchniową manifestacją ukrytych, wysoce abstrakcyjnych konstrukcji kognitywnych, a konstruowanie dyskursu polega na budowaniu siatki wzajemnie powiązanych przestrzeni mentalnych (Fauconnier, 1999). Wyrażenia językowe nie mają stałych znaczeń, cechuje je natomiast pewien potencjał znaczenia (meaning potential), „który w ramach danego dyskursu i w określonym kontekście aktualizuje się w postaci konkretnego sensu” (Libura, 2006: 71), a w budowaniu tego sensu ścierają się indywidualne i społeczne czynniki mentalne.

W procesie porozumiewania się członkowie różnych grup wyznają te same wartości, normy, konwencje komunikacyjne oraz społeczne reprezentacje wyrażające się w określonych modelach mentalnych oraz stereotypach, a jednocześnie w konkretnych sytuacjach komunikacyjnych wytwarzają i rozumieją teksty na swój jednostkowy sposób, powodujący personalne zróżnicowanie dyskursu. Celem badaczy włączających paradygmat kognitywny do analiz dyskursu jest wyodrębnienie czynników, które sprzęgają język z działaniem społecznym (por. Chilton, 2008). Dla przykładu: socjokognitywne podejście Van Dijka skonstruowane jest wokół standardowego psychologicznego modelu pamięci, który, łącząc pamięć semantyczną ze stabilnymi konstruktami społecznymi, traktuje pamięć epizodyczną jako magazyn wcześniej doświadczanych narracji, a pamięci roboczej przypisuje funkcje przetwarzania kontekstu. Badanie tego typu mechanizmów funkcjonowania ludzkiego umysłu ma ogromne znaczenie dla odkrywania czynników sprzyjających otwieraniu się uczestników dyskursu na różnego rodzaju wpływy (polityczne, kulturowe, społeczne) wywierane za pośrednictwem perswazji i manipulacji. 
Podejście kulturowe związane jest głównie $\mathrm{z}$ badaniem komunikacji wewnątrz- i międzykulturowej. Jego źródeł należy szukać w etnografii mówienia Della H. Hymesa, który ujmuje teorię mowy jako system zachowań kulturowych. Nie musi to być wcale system egzotyczny, to znaczy odnoszący się do kultur plemiennych lub kultur niewielkich społeczności etnicznych, będących obiektem tradycyjnie rozumianych badań antropologicznych i etnograficznych. Ważne jest, aby zachodzący w nim proces porozumiewania się rozpatrywać pod kątem specyficznych dla danej kultury struktur organizujących różnorodność form mowy (Hymes, 1980: 41). Podobny sposób myślenia znaleźć można w kulturoznawczych definicjach dyskursu. Skupiają się one nie tyle na manifestacji szczególnego sposobu i stylu wypowiadania się autora, ile na tym, co typowe, powtarzalne i kolektywne, czyli na tym, co pozwala odróżnić dyskursy poszczególnych kultur narodowych lub subkultur (Fleischer, 1994: 42).

Kulturowe ujęcie dyskursu jest niewątpliwie najszersze, umożliwia bowiem badanie aktualnych przekonań uczestników danej subkultury lub kultury. „Zespół tych przekonań, zmagazynowany w dyskursach, może być podstawą do tworzenia konstruktów określanych mianem językowych lub językowo-kulturowych obrazów świata" (Labocha, 1996b: 11).

Zestawienie przedstawionych powyżej podejść jest do pewnego stopnia arbitralne i nie wyklucza, oczywiście, innych możliwości porządkowania znaczeń nadawanych pojęciu „dyskurs”, zwłaszcza że podejścia te są w dużym stopniu komplementarne (na przykład podejście kulturowe i podejście kognitywne). Wszystkie też wpisują się w sformułowaną przez Teuna A. Van Dijka definicję dyskursu jako zjawiska, którego podstawę stanowią trzy główne wymiary: „użycie języka, procesy poznawcze oraz interakcje w ich społeczno-kulturowym wymiarze" (Van Dijk, 2001: 42).

\section{Interdyscyplinarne i lingwistyczne ujmowanie pojęcia „dyskurs"}

Uściślenie problematyki związanej z dyskursem edukacyjnym należałoby poprzedzić przedstawieniem i uporządkowaniem propozycji definiowania dyskursu, które pojawiły się na gruncie prezentowanych wcześniej podejść. Pierwszą grupę eksplikacji stanowią definicje sensu stricto odnoszące się do węższej interpretacji lingwistycznej, drugą zaś definicje sensu largo, wynikające z interdyscyplinarnego rozumienia dyskursu.

W ujęciu lingwistycznym kategoria dyskursu służy do określania jednostki językowej większej aniżeli pojedyncze zdanie, a przy tym uporządkowanej i sta- 
nowiącej całościowy, celowy, spójny ciąg językowy posiadający znaczenie (por. na przykład Numan, 1993: 154), często utożsamianej z tekstem (por. na przykład Żydek-Bednarczuk, 2005: 69). W jednostce tej przejawia się podmiot mówiący wraz z całą siecią relacji łączących go z adresatem wypowiedzi (por. na przykład Grabias, 1994: 264), przy czym wypowiedź rozumiana jest jako „pewien określony tekst, a więc konkretny przekaz słowny, dokonywany przez określoną osobę w danym akcie komunikacji i posiadający wszelkie znamiona indywidualnego użycia elementów językowych" (Dobrzyńska, 1991: 143)4. We współczesnych badaniach lingwistycznych, pod wpływem ustaleń poczynionych na gruncie pragmalingwistyki, socjolingwistyki i etnolingwistyki, ukształtował się sposób traktowania dyskursu, który, za Dominikiem Maingueneau (Grzmil-Tylutki, 2007: 24-26), sprowadzić można do następujących uogólnień:

1) dyskurs jest jednostką ponadzdaniową (istotny jest nie rozmiar wypowiedzi, ale jej aspekt całościowy jako makroaktu językowego);

2) dyskurs jest ukierunkowany (ma charakter pragmatyczny, zgodny $z$ intencją nadawcy i z przeznaczeniem, w które wpisany jest również odbiorca, choć dopuszczalne są także zmiany i modyfikacje);

3) dyskurs to forma działania (jest dynamiczny, rozwija się zgodnie z obranym celem);

4) dyskurs jest interaktywny (rozwija się w przestrzeni interpersonalnej);

5) dyskurs jest skontekstualizowany (kontekst stanowi jeden $\mathrm{z}$ immanentnych składników dyskursu, a nie wyłącznie jego tło);

6) dyskurs zakłada odpowiedzialność podmiotów, które go tworzą;

7) dyskurs podlega wzajemnie warunkującym się normom społecznym i językowym.

„Dyskurs” oznacza zatem „język w użyciu” i dotyczy sfery pośredniej między językiem rozpatrywanym w sposób abstrakcyjny i formalny, a konkretnymi tekstami. Zajęcie się jego analizą związane jest z koniecznością skierowania uwagi na konteksty pozajęzykowe, co, jak stwierdza Anna Duszak, pozwala przekroczyć granice tekstu, a tym samym pokonać wiele z ograniczeń tradycyjnej teorii tekstu, pozostając jednak nadal w jej pobliżu (Duszak, 1998: 20).

W ujęciu interdyscyplinarnym, stanowiącym efekt swoistego „zwrotu lingwistycznego", który w ciągu ostatnich dwudziestu lat dokonał się w metodologiach nauk społecznych (zwłaszcza w socjologii, psychologii społecznej i pedagogice),

\footnotetext{
${ }^{4}$ Podobny sposób definiowania dyskursu proponuje Anna Duszak: „dyskurs obejmuje całość danego aktu komunikacji, a więc zarówno określoną werbalizację (tekst), jak i czynniki pozajęzykowe, które jej towarzyszą, tj. przede wszystkim określoną sytuację użycia oraz jej uczestników” (Duszak, 1998: 19).
} 
dyskurs postrzega się jako ramy myślenia i argumentowania w danym obszarze życia społecznego. Obszar ten na ogół określany bywa przez wspólny przedmiot zainteresowania podmiotów uczestniczących w komunikacji, powtarzalność relacji społecznych oraz sposoby ich werbalizowania (zob. Krakowiak, 2008). Dyskurs nadaje postrzeganemu z określonej perspektywy obszarowi konkretne znaczenie, nie może być zatem traktowany wyłącznie jako zbiór tekstów, lecz jako połączenie tekstu z określonymi warunkami jego powstania. Tym samym interdyscyplinarne rozumienie dyskursu zakłada istnienie wzajemnego oddziaływania pomiędzy poszczególnymi rodzajami zachowań językowych a konkretnymi obszarami życia społecznego, w których one zachodzą. Oddziaływanie to wymaga wypracowania za pośrednictwem różnego typu interakcji komunikacyjnych pewnych wspólnych dla podmiotów komunikacji norm i wspomnianych wcześniej ram myślenia (zob. Habermas, 2004).

W konkretnych przedsięwzięciach badawczych te dwa zakresy rozumienia pojęcia „dyskurs”, czyli lingwistyczny oraz interdyscyplinarny, niejednokrotnie nakładają się na siebie i dlatego do ich analizy można zastosować tę samą procedurę badawczą, zaproponowaną przez Van Dijka. Obejmuje ona pięć kolejnych rodzajów działań:

[wyodrębnia] różne poziomy, jednostki, a także formułuje reguły i strategie ich normatywnych lub faktycznych użyć; odnosi do siebie te jednostki i poziomy na płaszczyźnie funkcjonalnej, a tym samym wyjaśnia, dlaczego zostały użyte. $W$ ten sposób funkcjonalnie wiąże struktury dyskursu ze strukturami społecznego i kulturowego kontekstu, a z kolei tak połączone zestawienia odnosi do struktur i strategii poznawczych. (Van Dijk, 2001: 43)

\section{Dyskurs edukacyjny}

Przedstawienie takiego sposobu rozumienia pojęcia „dyskurs edukacyjny”, które w pełni odzwierciedlałoby specyfikę uwarunkowań kontekstulanych (w tym ideologicznych), wymaga omówienia i uporządkowania obecnie funkcjonujących definicji dyskursu edukacyjnego oraz innych pojęć używanych do opisywania zachodzącej w edukacji komunikacji językowej. To, jak definiuje się dyskurs edukacyjny, w znacznej mierze zależy od tego, jak definiuje się samą edukację ${ }^{5}$. $Z$ rozmaitych ujęć procesu edukacji proponowanych w literaturze przedmiotu wyłaniają się dwa typy ujmowania zjawiska dyskursu edukacyjnego - mają one swój węższy i szerszy zakres.

\footnotetext{
${ }^{5}$ Zestawienia sposobów definiowania pojęcia edukacja podjęła się Barbara Guzik (Guzik, 2003).
} 
Przyjęcie zawężonego zakresu rozumienia edukacji ${ }^{6}$ skutkuje założeniem, że dyskurs edukacyjny to „uporządkowana interakcja werbalna, czyli współdziałanie nauczyciela i ucznia w wyrażaniu myśli na jakiś temat” (Kurczab, 1999: 284). Przytoczona tu definicja Henryka Kurczaba koresponduje z (również wąską) lingwistyczną definicją dyskursu zaproponowaną przez Renatę Grzegorczykową:

Dyskurs to większy (wielozdaniowy, na ogół dialogowy) tekst zawierający rozumowanie lub odpowiadającą mu jednostkę komunikacyjną, tzn. dłuższą wypowiedź tworzoną i percypowaną na żywo oraz zawierającą elementy rozumowania modyfikowanego w kontakcie z odbiorcą. (Grzegorczykowa, 1998: 42)

W rozumieniu Kurczaba dyskurs zajmuje w nauczaniu centralną pozycję i jest traktowany jako jedna $\mathrm{z}$ najistotniejszych form działania dydaktycznego, dzięki której jego uczestnicy doskonalą swoje umiejętności językowe i poznawcze ${ }^{7}$. W tym sensie mówić należy jednak nie tyle o dyskursie edukacyjnym, ile raczej o dyskursie „dydaktycznym” lub nawet „lekcyjnym”. Jolanta Nocoń, charakteryzując cechy dyskursu dydaktycznego, stawia wyraźną granicę między szerokim rozumieniem edukacji a znacznie węższym zakresem dydaktyki jako subdyscypliny pedagogiki zajmującej się nauczaniem i uczeniem w ich zarówno teoretycznym, jak i praktycznym wymiarze (Nocoń, 2009: 21). Zadaniem dyskursu dydaktycznego jest przeformowanie wiedzy z zakresu określonej dyscypliny naukowej w taki sposób, aby stała się ona przystępna dla odbiorcy mniej uczonego (por. Labocha, 1996b: $13)^{8}$, przy czym jest to „dyskurs zinstytucjonalizowany, dokonujący się w zorgani-

${ }^{6}$ Ograniczonego głównie do przekazywania wiedzy i umiejętności przygotowujących dzieci do obowiązków dorosłego życia.

7 Por. „Pojęciem dyskusji posługują się chętniej nauczyciele dla określenia sposobów, jakich używa się w celu zachęcenia uczniów do interakcji werbalnych. Natomiast termin dyskurs jest bliższy naukowcom i wskazuje na zainteresowanie nie tyle określonymi procedurami, co bardziej ogólnymi wzorcami wymiany i komunikacji, które występują w klasie szkolnej. Uczestnicy dyskursu posługują się językiem, który stanowi narzędzie komunikowania się. Za pomocą dyskursu doskonalą swoje umiejętności myślowe, poznawcze. Do czynników, które mają decydujący wpływ na ukształtowanie pozytywnego dyskursu, zalicza się szczere i otwarte komunikowanie się" (Kurczab, 1999: 284). W podobny sposób rozumie dyskurs edukacyjny Teodozja Rittel, uznając go za model pedagogicznej kompetencji komunikacyjnej, której celem jest wybór strategii nadawczo-odbiorczych i odpowiednio uporządkowanych problemów argumentacji. W tym ujęciu dyskurs edukacyjny stanowi jeden z gatunków mowy wykorzystywanych w procesie nauczania, a cechujący się strukturą semantyczną powiedzieć komuś coś i zawierający sądy, które są formułowane za pomocą wypowiadanych zdań, wywołujących przekonanie lub sprzeciw. Ponadto winien cechować się: szczerością, intencjonalnością, poprawnością językową oraz zaangażowaniem intelektualnym i emocjonalnym (Rittel, 1996: 99-100).

${ }^{8}$ Basil Bernstein stwierdza, że dyskurs pedagogiczny nie ma własnej, specyficznej treści dyskursywnej. Jest raczej zasadą przejmowania innych dyskursów i budowania między nimi szczególnego 
zowanych formach edukacji (w procesie nauczania-uczenia się) i w określonych ramach czasoprzestrzennych" (Nocoń, 2009: 21). Dyskurs lekcyjny jest pojęciem jeszcze węższym, odnosi się bowiem wyłącznie do wymiany aktów mowy między nauczycielem a uczniem (tak zwanego dialogu pedagogicznego lub szkolnego), zachodzącej w procesie kształcenia, a więc $w$ trakcie formowania wiedzy i realizowania celów dydaktycznych. Szkolna sytuacja komunikacyjna, w której dochodzi do tych kontaktów werbalnych, ma charakter oficjalny i publiczny, a cechuje ją swoista asymetria ról w układzie "nauczający-nauczany” (Skowronek, 1999: 12-13). Pojęciem o nieco szerszym zakresie znaczeniowym jest dyskurs „szkolny”, który odnosi się do form komunikowania się nauczyciela z uczniami także poza klasą lekcyjną, w przestrzeni szkoły jako budynku i jego otoczenia (Kawka, 1999: 29). Jolanta Nocoń poszerza tę definicję o zakres interakcji werbalnych uczeń-uczeń (Nocoń, 2009: 21)9.

Swoiste rozmycie pojęcia „dyskurs edukacyjny” sprawia, że często jego definicja w istocie ogranicza się wyłącznie do interakcji zachodzących na lekcji i odpowiada raczej węższemu pojęciu „dyskursu lekcyjnego”, tak jak na przykład w sformułowanej pod wpływem ustaleń psycholingwistów definicji Marii Zając, która przez dyskurs edukacyjny rozumie:

(...) strumień zjawisk językowych (mówionych i pisanych) pochodzących od nauczyciela i poszczególnych uczniów, które zachodzą w kontekście lekcji szkolnej i realizacji jej dydaktycznych założeń. Strumień ten, występujący w otoczce niewerbalnych zachowań komunikatywnych, wykorzystywany jest, zgodnie z przepisami roli społecznej ucznia i nauczyciela, w celu, który w płaszczyźnie działań prakseologicznych określić można w typowej lekcji szkolnej jako rozwiązywanie określonego zadania (problemu), w płaszczyźnie językowej zaś jako wspólne konstruowanie jakiegoś tekstu. (Zając, 1996: 78)

W szerszym rozumieniu edukacja oznacza proces przekazywania wiedzy, kształtowania umiejętności (zarówno umysłowych, jak i fizycznych), budowania własnej tożsamości oraz określonych cech osobowościowych, odnoszących się do sfery wartości etycznych i kulturowych. Edukacja może mieć charakter formalny - w szkole lub innego typu publicznych czy niepublicznych instytucjach oświatowych, ale może również przebiegać nieformalnie na podstawie własnych doświadczeń uczącego się oraz wpływu edukacyjnego rodziny, kręgów rówieśniczych, środowiska pracy, rynku, mediów, rozrywki. Tego typu edukacja nie koń-

stosunku w celu ich wybiórczego przekazywania i przyswajania (na zasadzie delokacji i relokacji elementów poszczególnych dyskursów) (Bernstein, 1990: 172).

9 Prezentacji polskich oraz światowych badań nad dyskursem szkolnym (dydaktycznym i lekcyjnym) dokonała Jolanta Nocoń (Nocoń, 2009: 18-24). 
czy się nigdy i obejmuje wszystkie obszary życia i osobowości człowieka, dlatego jej poszczególne typy różnicuje się, biorąc pod uwagę te właśnie obszary - stąd na przykład edukacja zdrowotna, fizyczna, obronna, ekologiczna czy ekonomiczna. W tak szerokim ujęciu dyskurs edukacyjny traktowany jest jako rozległa praktyka komunikacyjna, stanowiąca formę transmisji wiedzy z perspektywy eksperta do perspektywy nowicjusza i w obrębie określonego horyzontu kognitywnego; dyskurs ten powstaje w społecznych sytuacjach nauczania lub podczas szeroko rozumianego procesu kształcenia, co oznacza, że dotyczy każdej sytuacji włączania adepta we wspólnotę dyskursu, niezależnie od tego, czy praktyka ta ma charakter zinstytucjonalizowany czy nieformalny (por. Skudrzyk, 2005: 68; Nocoń, 2009: 20).

Dla naszych rozważań ważny jest fakt, że szerokie rozumienie edukacji związane jest $\mathrm{z}$ rozróżnianiem praktyk edukacyjnych na naturalne (nieformalne) oraz sformalizowane i zinstytucjonalizowane, które obejmują między innymi edukację szkolną sterowaną przez państwo, a więc podatną na wpływy władzy. Żadna z przedstawionych wyżej definicji dyskursu edukacyjnego nie odpowiada jednak w pełni przyjętej przeze mnie perspektywie badawczej, w definicjach tych bowiem nie założono explicite uwarunkowań ideologicznych, które wpływają na kreowanie znaczeń oraz na wartościowanie rzeczywistości. Uwarunkowania te dotyczą przede wszystkim edukacji sformalizowanej, reprezentującej tak zwany „wtórny porządek edukacyjny” (Jastrzębski, 2011: 18). W przeciwieństwie do edukacji naturalnej ${ }^{10}$ edukacja formalna reprezentuje sferę usług edukacyjnych oraz zinstytucjonalizowane i wyspecjalizowane, wielofunkcyjne praktyki społeczne, wyodrębnione na podstawie podziału pracy i ról zawodowych. Wszystko to razem tworzy kierowany przez państwo system oświatowo-wychowawczy, dla którego najbardziej reprezentatywną instytucją jest masowa szkoła powszechna z jej procesami, celami, formami organizacyjnymi, treściami, zasadami, programami i metodami.

${ }^{10}$ Edukacja naturalna dotyczy potocznych doświadczeń edukacyjnych, w których relacje opiekuńcze i edukacyjne typu „rodzic-dziecko” lub „pokolenie dorosłych-pokolenie dorastających”, uwikłane są w kontekst życia codziennego. Edukacja naturalna jest więc nierozerwalnie związana z ideą przetrwania, a także biologicznej i kulturowej ciągłości oraz reprodukcji. Na poziomie potocznym, zakorzenionym w tradycji społecznej spontanicznie i niejako bezrefleksyjnie akceptowana jest idea wychowania nie jako odrębnego rodzaju aktywności, ale jako organicznego (tak jak prokreacja) składnika procesów życiowych (por. Schulz, 2003: 124). W tak rozumianej edukacji naturalnej nie ma miejsca na świadomie i konsekwentnie prowadzone działania zmierzające do ideologizacji dyskursu. 


\section{Sformalizowany dyskurs edukacyjny w ujęciu procesualno-kognitywnym}

Przyjęty przeze mnie sposób opisywania dyskursu edukacyjnego, który nazywam dalej sformalizowanym dyskursem edukacyjnym, zakłada, że jest on swoistą społeczną praktyką językową zachodzącą w szkole, czyli w zinstytucjonalizowanej i formalnej sferze działań edukacyjnych. Jednocześnie zakładam, że ta redefinicja pojęcia „dyskurs edukacyjny” wymaga ukazania edukacji jako zjawiska uwikłanego w procesy społeczne, polityczne i kulturowe, przez które jest kształtowane i które jednocześnie kształtuje. Specyfika sformalizowanego dyskursu edukacyjnego polega więc na tym, że stanowi on praktykę językową, w której ścierają się rozmaite procesy społeczne, polityczne i kulturowe wraz z towarzyszącymi im praktykami językowymi ${ }^{11}$. Wnoszą one do sformalizowanego dyskursu edukacyjnego cechy innych dyskursów (na przykład dyskursu politycznego, naukowego). W konsekwencji do dyskursu edukacyjnego włączane są teksty ujęte w gatunki prymarne dla innych dyskursów, na przykład: utwory literackie, szkice naukowe, artykuły prasowe oraz rozmaite teksty kultury - rzeźby, obrazy, obiekty architektoniczne, filmy fabularne itp., co nadaje mu swoiście interdyskursowy oraz intersemiotyczny charakter.

Na konkretne realizacje tekstów, na model gatunków, w które zostały one ujęte w dyskursie edukacyjnym, wpływają zarówno specjalistyczne dyskursy dyscyplin naukowych, z których pochodzi baza pojęciowa tradycyjnych przedmiotów szkolnego nauczania oraz dyskursy dyscyplin współtworzących teorie nauczania, a więc na przykład pedagogiki, psychologii rozwojowej, jak i rozmaite typy dyskursów publicznych ze wspomnianym dyskursem politycznym na czele. Takie założenie pozwala analizować na jednej płaszczyźnie nie tylko jednoznacznie przypisany dyskursowi edukacyjnemu i prymarny dla niego gatunek, jakim jest podręcznik, ale i na przykład podstawę programową, programy nauczania czy akty prawne dotyczące oświaty. Ich konkretne realizacje (poza podręcznikiem) nie stanowią bezpośredniego przedmiotu dyskursu lekcyjnego, ale wpływają (lub w założeniu - mają wpływać) na jego kształt. Jednocześnie wszystkie te gatunki (łącznie z podręcznikiem) wymagają aprobaty nie tylko grona reprezentujących różne dziedziny ekspertów, ale również Ministerstwa Edukacji Narodowej, które jest przecież

${ }^{11}$ Podobne rozumienie kontekstu dyskursu edukacyjnego prezentuje Jolanta Nocoń: „społeczny zakres dyskursu edukacyjnego jest szeroki: nie ogranicza się do ram instytucji zajmujących się edukacją społeczeństwa, w tym przede wszystkim szkoły, ale odnosi się do wszystkich sytuacji komunikacyjnych, w których zachodzi proces włączania adepta we wspólnotę dyskursu" (Nocoń, 2009: 20). 
agendą rządu, podlegają także debacie społecznej, na przykład w parlamencie lub w mediach.

Za pośrednictwem edukacji powstaje określona wspólnota interpretacyjna, która artykułuje pewne znaczenia zarówno na gruncie języka - w tekstach, jak i poprzez szeroko rozumiany kontekst. Na tej płaszczyźnie dyskurs traktować można jako pole wspólnego negocjowania znaczeń przez uczestników określonych praktyk. Tak zdefiniowany dyskurs nie odnosi się do sfery indywidualnej, ale stanowi swoisty aspekt świata kultury, funkcjonuje w obrębie określonych środowisk, instytucji i procesów, współtworząc je i określając ich charakter. Będąc ustrukturyzowany przez język i kontekst, dyskurs jednocześnie sam strukturyzuje rzeczywistość.

W przyjętym tu sposobie rozumienia pojęcia „dyskurs edukacyjny” o wiele silniej wyeksponowane zostało podejście procesualne, które akcentuje związki między negocjowaniem znaczeń a charakterem stosunków społecznych, oraz podejście kognitywne, przypisujące duże znaczenie nie tylko właściwym każdemu podmiotowi procesom mentalnym, ale także uwarunkowanym społecznie i kulturowo reprezentacjom, takim jak: wiedza, postawy, ideologie, normy oraz wartości, przyjmowanym przez użytkowników języka jako członków określonych grup.

Oddziałujące na dyskurs edukacyjny uwarunkowania kontekstualne rozpatrywać można w aspekcie lokalnym lub globalnym (Van Dijk, 2001: 29). Definiując, a następnie analizując sformalizowany dyskurs edukacyjny, należy uwzględnić oba te aspekty: kontekst lokalny, odnoszący się do miejsca, okoliczności, uczestników, ich ról komunikacyjnych i społecznych (na przykład uczeń - nauczyciel, uczeń uczeń), intencji, celów, oraz kontekst globalny obejmujący praktyki komunikacyjne, które uznać można za działalność konstytuującą organizacyjnie lub instytucjonalnie postępowania i procedury edukacyjne, a których uczestnicy są przedstawicielami różnych grup społecznych bądź instytucji (na przykład rozmaitych agend rządowych, gremiów opiniotwórczych, nadzoru pedagogicznego itp.). Kontekst lokalny ma zatem charakter spersonifikowany, zindywidualizowany i jednostkowy, kontekst globalny zaś odnosi się do instytucjonalnej sfery procedur edukacyjnych.

W ujęciu procesualno-kognitywnym dyskurs edukacyjny nie jest arbitralnym zbiorem tekstów, tworzą go formy językowe powiązane z konkretną, uwarunkowaną socjologicznie, historycznie i politycznie praktyką społeczną. Ma swoje korzenie w historii, ale jednocześnie wpływa na teraźniejszość i kształtuje przyszłość, jego analiza wymaga więc uwzględnienia wszelkich możliwych informacji o kontekście, łącznie z, tak istotnym dla nauczania, kontekstem kognitywnym. Dyskurs edukacyjny kształtuje bowiem nie tylko indywidualne osądy rzeczywistości, ale przede wszystkim kreuje tożsamość zbiorową (kolektywną) młodego pokolenia, 
obejmującą odpowiednio wyselekcjonowane wzory kultury, zespół norm i wartości oraz zasady porządkujące wiedzę. Jest również „miejscem, w którym język styka się z ideologią" (Pêcheux, 1988: 635). Istotne jest więc badanie ideologicznych wymiarów używania języka w szkole, a zwłaszcza zmian, jakie wraz z przemianami ideologicznymi, dotyczącymi zarówno sfery polityki, jak i kultury oraz życia społecznego, zachodzą w znaczeniach kluczowych dla edukacji pojęć, takich jak na przykład: „ojczyzna”, „mowa ojczysta”, „przyroda”, „,cywilizacja”. Powstające w jego obrębie, a następnie przekazywane młodemu pokoleniu znaczenia, które odnoszą się do różnych zjawisk rzeczywistości, negocjowane są pod wpływem kontekstu. Ten z kolei odzwierciedla relacje władzy oraz rozmaite ideologie.

Uczestnicy dyskursu edukacyjnego nie są zazwyczaj świadomi sposobów, w jakich dochodzi do pozycjonowania ich poprzez szkołę jako instytucję, a w konsekwencji do przyjmowania przez nich określonych ról społecznych. Świadomość tę zmienić może ukazywanie mechanizmów perswazji oraz manipulacji językowej, które wpisane zostały w oficjalne dokumenty oświatowe oraz teksty zamieszczone w podręcznikach. W ten sposób zbadać można także kwestie nadużywania władzy i odtwarzania nierówności za pomocą ideologii.

\section{Obszary społecznego działania w dyskursie edukacyjnym}

Bez analizy kontekstu trudno jest określić zakres i charakter ideologizacji wpisanej w działalność szkoły jako instytucji uwikłanej w procesy społeczno-polityczne. Zorganizowane przez nią kształcenie dorastającego pokolenia włączane jest w sferę oddziaływania kierowanego przez państwo aparatu władzy, na skutek czego uczenie się może być kontrolowane administracyjnie oraz poddawane wpływom politycznym. Instytucjonalnych ingerencji w procesy pedagogiczne nie można zatem interpretować jedynie jako niezamierzonych działań ubocznych. Są one integralną cechą kompleksowego systemu szkolnictwa obowiązkowego, znajdującego się pod nadzorem państwa. Szkoła jako instytucja zapewnia nie tylko ciągłość nauczania, ale zarazem stwarza przesłanki do celowego i planowego wywierania ideologicznego wpływu na dorastające pokolenie (Tillmann, 1996: 155). Wpływ ten nie ogranicza się wyłącznie do ideologii stricte politycznych, zwłaszcza że na ogół trudno jednoznacznie rozdzielić sfery oddziaływań poszczególnych idei, które niejednokrotnie wzajemnie się uzupełniają i wzmacniają, na przykład: w polskich szkołach pozytywistyczna ideologia modernizmu społecznego, głosząca kult postępu cywilizacyjnego, wspierała ideologię państwowotwórczą w latach trzydziestych XX wieku, a następnie wykorzystywana była do legitymizowania no- 
wego ustroju przez ideologię komunistyczną w okresie PRL, zaś obecnie stała się celem konfrontacji z ideologią tak zwanej ekologii głębokiej.

Cele, natężenie oraz zakres oddziaływania ideologicznego, niezależnie od tego, czy dotyczą aktualnej polityki państwa, czy też kultury lub określonych sfer życia społecznego, zawsze w jakiś sposób zależą od pozycji zajmowanych w hierarchii władzy przez tych, którzy określone przesłania ideologiczne głoszą. Im pozycja ta jest silniejsza, tym większa jest skala oddziaływań danej ideologii, która swym wpływem może obejmować znaczną część społeczeństwa.

Sformalizowana edukacja jest skutecznym narzędziem wpływania na różne sfery świadomości społecznej, sama też zmienia się pod wpływem nacisków płynących z różnych ośrodków opiniotwórczych. Dla przybliżenia specyfiki właściwego dyskursowi edukacyjnemu kontekstu społeczno-politycznego warto posłużyć się stosowanym w krytycznej analizie dyskursu pojęciem „obszaru działania społecznego”. Oznacza ono konkretny wycinek rzeczywistości społecznej, który stanowi odniesienie dla danego dyskursu. Istotne jest, że zróżnicowaniu na poszczególne obszary działania społecznego odpowiada zróżnicowanie funkcji i społecznej instytucjonalizacji działań dyskursywnych (Wodak, 2008: 190). W ten sposób funkcje realizowane w dyskursie edukacyjnym powiązać można z poszczególnymi funkcjami sformalizowanej edukacji.

Przyjmuję, że sformalizowany dyskurs edukacyjny znajduje odniesienie w następujących zasadniczych obszarach działania społecznego: socjalizacji, selekcji (doborze), międzypokoleniowej transmisji wzorów kultury (enkulturacji), międzypokoleniowej transmisji wiedzy, realizacji polityki edukacyjnej państwa oraz nadzorze pedagogicznym. To właśnie w tych obszarach realizują się zasadnicze funkcje sformalizowanej edukacji, które najogólniej sprowadzić można do:

1) wybierania i przekazywania młodemu pokoleniu wzorów kultury, postaw, wiedzy, umiejętności uznanych za istotne dla przetrwania społeczności;

2) stratyfikacji społecznej;

3) przygotowania do świata pracy.

\section{Wymiar poznawczy (ideologiczny) dyskursu edukacyjnego}

Badając dyskurs edukacyjny, można uwzględniać różne jego wymiary - językowy, komunikacyjny, interakcyjny oraz poznawczy. Wymiar językowy obejmuje ustrukturyzowane grafemy i dźwięki, abstrakcyjne formy składniowe, kompleksowe struktury lokalnych i globalnych znaczeń oraz schematyczne formy kompozycyjne. Dwa kolejne wymiary związane są z działaniami społecznymi realizowa- 
nymi przez użytkowników języka, którzy komunikują się między sobą w różnych sytuacjach w obrębie określonego społeczeństwa i danej kultury (Van Dijk, 2001). Dla podjętych w tym artykule rozważań szczególnie interesujący wydaje się ostatni $\mathrm{z}$ wymienionych wymiarów - to on decyduje bowiem o tym, jak użyte i zrozumiane zostaną poszczególne wyrazy, zdania i schematy narracyjne, sposoby budowy oraz uzyskiwania koherencji tekstu, a także o tym, jak będą zastosowane i odczytane rozmaite strategie komunikacyjne stosowane przez uczestników dyskursu. Jak zauważa Teun Van Dijk:

Ludzie są w stanie zrozumieć zdanie, osiągnąć spójność między zdaniami albo uchwycić sens tekstu pod warunkiem, że podzielają pewien wspólny repertuar społeczno-kulturowych przekonań. Wybór jednostek leksykalnych, alternacje stylistyczne, użycie środków retorycznych wszystko to implikuje, że użytkownicy języka wyrażają swoje opinie lub ideologie, a także wnoszą swój wkład w tworzenie nowych lub przekształcanie już istniejących. (Van Dijk, 2001: 26)

Wymiar poznawczy dyskursu odnosi się zatem do pewnych społecznie akceptowanych systemów aksjologicznych, które ułatwiają członkom danej społeczności uporządkowanie obrazu świata i określają punkt wyjścia sądów wartościujących różne zjawiska rzeczywistości - zarówno tej istniejącej realnie, jak i tej pozostającej w sferze pragnień. Organizowaniu wspólnot światopoglądowych funkcjonujących w poszczególnych grupach społecznych służą rozmaite ideologie i dlatego wymiar poznawczy dyskursu można nazwać także wymiarem ideologicznym.

Terminem „ideologia” posługuję się, mając świadomość trudności definicyjnych wynikających $\mathrm{z}$ tego, że jest on używany do opisu zbioru przekonań dotyczących różnych poziomów życia społecznego i bywa w związku z tym stosowany $\mathrm{w}$ różnorodnych kontekstach ${ }^{12}$. W przypadku analizowania interesujących mnie tekstów włączonych do dyskursu edukacyjnego, wieloznaczność ta nie stanowi jednak przeszkody, a nawet pozwala pełniej opisać ich warstwę ideową. Dzięki takiemu podejściu, można bowiem uwzględnić przesłania różnego typu ideologii, nie tylko politycznych, ale także społecznych, kulturowych i edukacyjnych. Jest to o tyle ważne, że w edukacji szczególnie trudno oddzielić sfery ich oddziaływania, dla przykładu: pozyskaniu dominacji przez grupę społeczną kierującą się konserwatywną ideologią polityczną może służyć autorytarna ideologia edukacyjna, w którą z kolei wpisana jest ideologia zorientowana na uniwersalistyczną kulturę wysoką ${ }^{13}$.

${ }_{12}$ Zob. dyskusje nad wieloznacznością terminu „ideologia”: Szacki, 1991; Bauman, 1998; Puzynina, 2008.

${ }^{13}$ Zdaniem Rolanda Meighana „ideologie edukacyjne operują na różnych poziomach i mają kilka warstw znaczeniowych - narodową w ustawach o szkolnictwie, regionalną w polityce lokalnych 
Ta właśnie różnorodność zadecydowała o tym, że używając terminu „ideologia”, nie odwołuję się do zawężonych definicji projektujących, typowych dla dyskursów takich dyscyplin, jak na przykład socjologia lub politologia. Moją inspirację stanowi ogólna, opisowa definicja zaproponowana przez Jadwigę Puzyninę, według której ideologia to:

zespół poglądów, zazwyczaj także zasad postępowania i haseł, charakterystyczny dla jakiejś grupy społecznej, oparty na określonych wartościach, dotyczący całościowych koncepcji człowieka i/lub życia społecznego albo ich fragmentów. Ideologie często są powiązane z jakimiś kierunkami myśli politycznej, ekonomicznej, estetycznej lub innej. Są one w jakiejś mierze zależne od stosunków społecznych i całości kultury, w obrębie której powstają. Różnią się między sobą stopniem racjonalności oraz mniejszym lub większym udziałem czynników emocjonalnych (...). Zdecydowanie negatywną ocenę uzyskują ideologie o charakterze totalitarnym, w taki czy inny sposób narzucane członkom społeczeństwa. (Puzynina, 2008: 20)

Przytoczona tu definicja pozwala traktować ideologię nie tylko jako narzędzie do obrony politycznych czy ekonomicznych interesów jakiejś grupy społecznej, ale także jako rodzaj swoistych reprezentacji kognitywno-społecznych, które przejawiają się przez język. Zbiór przeświadczeń składających się na jakąś ideologię nie musi być jednorodny, uporządkowany ani spójny - może on wchłaniać elementy wewnętrznie i wzajemnie sprzeczne, sądy wartościujące i konstatacje opisowe zaczerpnięte $z$ różnych systemów wiedzy (zarówno potocznej, jak i naukowej) oraz różnych obszarów doświadczeń pochodzących z rozmaitych poziomów i rejonów kultury. Przeświadczenia te stanowią swoisty rodzaj interpretacji rzeczywistości. Dyskurs można badać na trzech jego płaszczyznach: leksykalnej, gramatyczno-tekstowej oraz tekstowej. Wybieram tę trzecią, co pozwala na odwoływanie się do doświadczeń językoznawczych koncepcji kognitywistycznych, a zwłaszcza tekstologicznej szkoły lubelskiej stworzonej przez Jerzego Bartmińskiego oraz Ryszarda Tokarskiego.

Według Bartmińskiego wspomnianą wcześniej interpretację rzeczywistości uznać można za rezultat:

subiektywnej percepcji i konceptualizacji rzeczywistości przez mówiących danym językiem, ma więc charakter wyraźnie podmiotowy, antropocentryczny, ale zarazem jest intersubiektywna w tym sensie, że podlega uspołecznieniu i staje się czymś, co łączy ludzi w danym kręgu społecznym, czyni z nich wspólnotę myśli, uczuć i wartości; czymś, co wtórnie wpływa (z jaką siłą - to już jest przedmiotem sporu) na postrzeganie i rozumienie sytuacji społecznej przez członków wspólnoty. (Bartmiński, 2010)

władz oświatowych, lokalną w danej szkole. Ideologie edukacyjne są ponadto związane z innymi ideologiami - politycznymi, ekonomicznymi, ideologiami klas społecznych" (Meighan, 1993: 197). 
Powyższa konstatacja, zapożyczona ze sformułowanej przez Jerzego Bartmińskiego definicji językowego obrazu świata, kieruje uwagę na kognitywnie zorientowaną etnolingwistykę oraz wypracowane przez nią narzędzia i kategorie badawcze, które można wykorzystać do zbadania obszaru owych intersubiektywnych i uspołecznionych interpretacji, składających się na określone ideologie.

Jednym $\mathrm{z}$ takich narzędzi służących do analizy wartości ukrytych w językowo ukonstytuowanym obrazie świata jest kategoria „punktu widzenia”. Ten aspekt badań semantycznych wiąże się z pojęciem „profilowania”, które, niezależnie od jego konkretnych odczytań i sposobów definiowania ${ }^{14}$, zorientowane jest (najogólniej rzecz ujmując) na interpretację tekstową słowa. Profile można zatem uznać za warianty wyobrażenia przedmiotu hasłowego, nie zaś za warianty znaczenia - dana jednostka językowa może posiadać alternatywne profile, nie stanowią one jednak jej alternatywnych znaczeń.

W konkretnym dyskursie (na przykład w dyskursie edukacyjnym) jako formie debaty społecznej uczestniczą różne podmioty mówiące, reprezentujące zbieżne bądź odmienne interesy i punkty widzenia, a przez to ostatecznie systemy wartości. To nie gdzie indziej jak tylko w dyskursie dochodzi do głosu polaryzacja punktów widzenia, mająca bezpośredni wpływ na proces subiektywnego profilowania rzeczywistości. Wyraża się on w różnych formach dyskursywnej werbalizacji bądź w strategiach dyskursywnych, które konkurują ze sobą (Czachur, 2011: 82). Profilowanie można wówczas postrzegać jako proces wartościowania oparty na przyjętych przez mówiących wartościach i ich punktach widzenia, które z kolei wynikają z aktywowania typowego dla danej społeczności paradygmatu kulturowego, obejmującego wzory myślenia i przekonania.

Masowa, zinstytucjonalizowana edukacja stanowi jeden $\mathrm{z}$ najbardziej powszechnych, a zarazem najbardziej jednorodnych elementów kształtowania indywidualnych osądów rzeczywistości. Owa jednorodność przekazu odróżnia edukację od mediów, których oddziaływanie jest równie (o ile nie bardziej) powszechne, ale już nie tak homogeniczne. Media dopuszczają do głosu (wprawdzie na różnych prawach) najrozmaitsze ośrodki opiniotwórcze - od elit rządzących po niszowe subkultury rozpowszechniające swe ideologie za pośrednictwem na przykład Internetu. W efekcie to samo zjawisko może być wartościowane i interpretowane na wiele, nierzadko diametralnie różnych sposobów. Przeciwnie dzieje się w zinstytucjonalizowanej edukacji, niedopuszczającej innych punktów widzenia, które

${ }^{14}$ Chodzi tu głównie o różne sposoby redefiniowania pierwotnej koncepcji Ronalda Langackera (1995), według którego profilowanie to operacja mentalna dokonywana przez umysł ludzki, polegająca na podświetlaniu pewnego elementu w obrębie bazy tak, że element ów uzyskuje szczególny stopień wyróżnienia. 
mogłyby konkurować ze sobą i w rezultacie odmiennie profilować obraz świata. Edukacja przedstawia dorastającemu pokoleniu, które nie ma jeszcze własnych doświadczeń i spolaryzowanych na ich podstawie przekonań, gotową konstrukcję wyobrażeń rzeczywistości i tym samym wpływa na kształtowanie się kolektywnej tożsamości. Owa zbiorowa świadomość obejmuje zarówno odpowiednio wyselekcjonowane wzory kultury, jak i zespół norm oraz wartości, w skład których wchodzą także zasady porządkujące wiedzę.

\section{Metody analizy sformalizowanego dyskursu edukacyjnego}

Wspomnianą wcześniej metodą badawczą, która pozwala na refleksje nad dyskursem edukacyjnym, jest krytyczna analiza dyskursu. Nie stworzyła ona, jak wiadomo, jednego paradygmatu badawczego. Norman Fairclough i Ruth Wodak za najistotniejsze dla KAD podejścia uznają: francuską szkołę analizy dyskursu, lingwistykę krytyczną, semiotykę społeczną, badania społeczno-kognitywne, metodę dyskursywno-historyczną, analizę lekturową, metodę szkoły duisburskiej oraz badania nad wzajemnymi wpływami między zmianami społeczno-kulturowymi a zmianami w dyskursie (Fairclough, Wodak, 2006: 1051-1056) ${ }^{15}$. Dotychczas tylko nieliczne z tych podejść wykorzystane zostały do badania konkretnych zjawisk dyskursu edukacyjnego. Przedstawiciele francuskiej szkoły analizy dyskursu podejmowali się oglądu podręczników szkolnych, także w kontekście genologicznym (por. Grzmil-Tylutki, 2007). Reprezentanci lingwistyki krytycznej zajęli się niektórymi tekstami edukacyjnymi w celu prześledzenia ideologicznego potencjału systemów kategoryzacji wbudowanych w określone sposoby leksykalizacji doświadczeń ujętych w tego typu tekstach (Kress, 1985). Metodę dyskursywno-historyczną stosowano do analizowania barier w komunikacji instytucjonalnej w szkole (Wodak, Koller, 2008). Z kolei badania nad związkiem między zmianą społeczno-kulturową a zmianą dyskursywną zaowocowały propozycjami pedagogicznego zastosowania tak zwanej „krytycznej świadomości językowej” jako centralnego składnika edukacji językowej w szkołach i innych placówkach edukacyjnych (por. Fairclough, 1992).

Poszczególne projekty KAD czerpią z różnych teorii i dokonań badawczych, stosownie do podejmowanej tematyki i obiektu, który konstruują. Przyjęty przeze mnie sposób rozumienia dyskursu edukacyjnego jako nacechowanej interdyskur-

15 Por. także, oparty na odmiennych kryteriach, sposób wyodrębnienia poszczególnych nurtów krytycznych badań nad dyskursem przedstawiony przez Paula Chiltona (Chilton, 2008: 62-64). 
sywnością praktyki społecznego porozumiewania się, stanowiącej obszar ścierania się tendencji do dominacji i emancypacji, służący w równej mierze zmianom, jak i stabilizacji, pozwala na wybór elementów właściwych różnym podejściom krytycznym. Ich zastosowanie zmniejsza ryzyko jednostronnego podejścia do przedmiotu badań. Tę wielotorowość prac badawczych zapewnia między innymi metoda wieloaspektowa, polegająca na łączeniu rozmaitych procedur analitycznych i uwzględnianiu różnorodnych danych empirycznych oraz informacji kontekstowych. Jej geneza wywodzi się ze szkoły wiedeńskiej, która uprawia historyczną analizę dyskursu (HAD), stanowiącą jedną z odmian krytycznej odmiany dyskursu. Ruth Wodak, czołowa badaczka tej grupy, poszerzyła obszar analiz nie tylko o odwołania do teorii socjologicznych, ale także o historyczny wymiar działań dyskursywnych na drodze badania przemian diachronicznych, którym podlegają poszczególne gatunki dyskursu ${ }^{16}$.

Za kluczowe pojęcie metody wieloaspektowej uznaje się „kontekst”, tak istotny z perspektywy przyjętego przeze mnie sposobu definiowania dyskursu edukacyjnego. Ruth Wodak wyznacza następujące poziomy kontekstu:

1) bezpośredni kontekst językowy, tekstowy;

2) międzytekstowe i międzydyskursywne związki pomiędzy wypowiedziami, tekstami, gatunkami mowy, dyskursami;

3) pozajęzykowe zmienne społeczne, socjologiczne i instytucjonalne ramy poszczególnych kontekstów sytuacyjnych;

4) szerszy kontekst społeczny, polityczny i historyczny działań dyskursywnych (Wodak, 2008: 193).

Na dobór konkretnych kategorii i narzędzi badawczych wpływ ma rodzaj i charakter aktualnie podejmowanej problematyki. Chodzi o to, aby osiągnąć jak największą skuteczność w teoretycznym analizowaniu zjawisk społecznych i językowych, jego ostatecznym celem jest bowiem praktyczne zastosowanie wyników badań, które powinny być udostępnione specjalistom z różnych dziedzin, a następnie wykorzystane do zmiany pewnych praktyk społecznych (Wodak, 2008: 194). W tym celu metoda wieloaspektowa analizy dyskursu powinna obejmować ustalenie treści/tematów konkretnej wypowiedzi oraz badanie użytych w niej strategii dyskursywnych (w tym sposobów argumentacji), środków językowych i gatunków mowy oraz ich konkretnych, uzależnionych od kontekstu realizacji (okazów) (Wodak, 2008: 195).

${ }^{16}$ Szerzej o założeniach historycznej analizy dyskursu zob.: Wodak, 2008 i Wodak, Krzyżanowski, 2011. 
Przez pojęcie „strategii” R. Wodak rozumie mniej lub bardziej ściśle określony, czy świadomie przyjęty program działań (w tym i działań dyskursywnych) zmierzający do osiągnięcia konkretnych społecznych, politycznych, psychologicznych lub językowych celów (Wodak, 2008: 195). Strategie dyskursywne to natomiast „systematycznie powtarzające się sposoby użycia języka, charakteryzujące rozmaity stopień złożoności oraz przypisanie do różnych poziomów organizacji systemu językowego" (Wodak, 2008: 196). Przyjęcie takiego założenia sprawia, że do badania dyskursu stosować można narzędzia właściwe analizie retorycznej. Pozwala ona na wyszczególnienie nie tylko strategii perswazyjnych oraz ich celów, ale także środków, jakimi są one realizowane.

Do inspiracji tradycją retoryczną skłania kilka zasadniczych względów. Pierwszym z nich jest wielki renesans retoryki, która przez dłuższy czas uchodziła za dyscyplinę ostatecznie zamkniętą i ograniczoną do spetryfikowanych wzorów klasycznej wymowy. Tymczasem, zapoczątkowany w latach sześćdziesiątych ubiegłego wieku rozwój gramatyki tekstu oraz lingwistycznej teorii prozy sprawił, że retorykę poczęto postrzegać nie tylko w kategoriach wiedzy o już sprawdzonych technikach argumentacji, ale także, a może nawet przede wszystkim, jako technikę generatywną, która, dzięki dysponowaniu pewnymi mechanizmami argumentacyjnymi, pozwala na generowanie przekonujących argumentów, dostosowanych do aktualnych potrzeb (Ziomek, 1986: 94).

\section{Badanie argumentacji jako sposób analizy przekazu ideologicznego w dyskursie edukacyjnym}

Uniwersalny charakter retoryki polega na tym, że opisuje ona pewne prawidłowości konstrukcji wszelkich tekstów oraz posługiwania się nimi. Przedmiotem badań retorycznych staje się język w działaniu bądź język użyty przez człowieka w celu kształtowania postaw lub wywoływania działań innych ludzi. Podejmowane współcześnie badania nad retoryczną strukturą tekstów służą wyjaśnianiu dynamicznych oddziaływań między wypowiedzią perswazyjną a jej kontekstem ${ }^{17}$.

${ }_{17}$ Najbardziej rozpowszechnione obecnie metody analizy retorycznej przedstawił Jakub Z. Lichański (2007: 20-26). Są to: 1) metoda ukształtowana przez amerykańską szkołę rhetorical criticism, 2) metoda zaproponowana przez Rolanda Barthesa (zob. także Barthes, 1997); 3) metoda analizy argumentacji Chaima Perelmana (zob. Perelman 1995); 4) metoda pięciostopniowa. Przebieg analizy retorycznej wywodzącej się z nurtu amerykańskiej krytyki retorycznej wraz z przykładem jej praktycznego zastosowania przedstawiły Ann M. Gill i Karen Whedbee (2001). Warto zaznaczyć, że krytykę retoryczną (podobnie jak KAD) bardzo często stosuje się do badań nad dyskursem grup wykluczonych (tzw. „Innych”), w tym nad dyskursem feministycznym. 
Oznacza to, że w polu zainteresowań badaczy znajduje się przede wszystkim sposób, w jaki dyskurs odpowiada na potrzeby odbiorców, jak wspiera lub zmienia ich przekonania i wpływa na strukturę społeczną grupy (Gill, Whedbee, 2001: 185), dlatego też, zdaniem Teuna Van Dijka, retoryka może być uważana za poprzedniczkę tego, co dziś określamy jako analizę dyskursu (Van Dijk, 2001: 21).

Jeśli za cel badania sformalizowanego dyskursu edukacyjnego przyjmiemy sprawdzenie tego, w jaki sposób kształtowana jest w nim ideologicznie nacechowana zbiorowa tożsamość młodego pokolenia, głównym przedmiotem analiz nie będą poszczególne sekwencje argumentacyjne, ale miejsca wspólne (loci communes; topoi), z których czerpane są argumenty. Analiza procesu argumentacyjnego wymagałaby dokładnego badania kompozycji retorycznej poszczególnych tekstów właściwych temu typowi dyskursu. Drobiazgowe odtwarzanie struktur semantycznych konstruowanych w konkretnych tekstach (na przykład w podręcznikach, podstawach programowych, dokumentach oświatowych) utrudniłoby uchwycenie zasadniczych punktów odniesienia, stanowiących zaplecze pojęciowe uczestników sformalizowanego dyskursu edukacyjnego. Wskazanie toposów pozwala natomiast na wyodrębnienie pewnych obiegowych sądów, schematów i obrazów, do których odwoływano się, kształtując świadomość kolejnych pokoleń uczniów. Toposy nie mają wartości informacyjnej, nie mówią niczego, czego wcześniej odbiorca nie uświadamiałby sobie i czego by nie oczekiwał w określonych okolicznościach, a jednocześnie służą do zmiany rzeczywistości społecznej i przyjęcia przez odbiorcę określonej interpretacji świata. W tym sensie toposy służą kreowaniu ról społecznych i zachodzących między nimi relacji, określają system społecznie ważnych wartości i podtrzymują wersję rzeczywistości przyjętą przez nadawcę. Ich funkcja polega na ustalaniu i utrwalaniu wśród członków danej grupy preferowanych przez nadawcę znaczeń. Retoryczne „miejsca wspólne” stosowane są w procesie perswazji, której celem nie jest dotarcie do prawdy bezosobowej i obiektywnej, lecz uzyskanie zarówno intelektualnej, jak i emocjonalnej akceptacji twierdzeń sformułowanych przez nadawcę. W ten sposób toposy przyczyniają się do powstania swoistych ram, czy też modeli pojęciowych wspólnych dla kolejnych, kończących szkołę pokoleń.

W sferze propagowania ideologii toposy pełnią zwykle funkcje impresywne mają pobudzać, stymulować do działania lub wpływać na stan mentalny uczestników dyskursu. Zależnie od tego, czy zostały zastosowane do jawnego wywierania wpływu na świadomość odbiorców, czy też używane są podprogowo - stanowią środek perswazji lub manipulacji. $\mathrm{W}$ tym celu włączane są w szersze struktury znaczeniowe, tworzące $\mathrm{w}$ dyskursie swoisty odpowiednik całościowych ram czy też modeli pojęciowych. 
W warstwie ideologicznej dyskursu modele te obejmują wiedzę związaną zarówno z poznaniem racjonalnym, jak i z typem poznania, które można by nazwać racjonalnością mityczną, charakteryzującą się dużym stopniem ekspresywności i silną stereotypizacją. Myślenie mityczne służy modelowaniu rzeczywistości (a w pewnym sensie także jej zaklinaniu) oraz nadawaniu jej sensów niepodlegających dyskusji. Ma charakter wybiórczy, skrótowy i jednowymiarowy. Często skupia uwagę na nieistotnych epizodach, którym nadaje rangę wielkich zdarzeń i swoistych symboli. W mitycznej percepcji rzeczywistości nierzadko podstawą do przekonania o zależności przyczynowej staje się jeden fakt, nie ma też rozróżnienia na wyobrażenie i przedmiot, na rzecz i jej obraz. Z tego powodu tak często wykorzystywane jest ono w nacechowanej ideologicznie (zwłaszcza politycznie) perswazji (por. między innymi Jaźwiński, 2008; Jeziński, 2008). Na jej użytek kreowane są mity polityczne (na przykład mit genezy lub mit herosa legitymizujące powstanie narodu, państwa lub ustroju politycznego) oraz mity społeczne (do których należą między innymi mity edukacyjne, takie jak na przykład mit równości szans edukacyjnych lub mit wszechstronnego rozwoju ucznia). Objęte mitologizacją tematy dyskursu są relatywizowane w zależności od okresu, w jakim się pojawiają, zawsze jednak mit tworzy system odniesień, dzięki którym nadawcy nadają odpowiednie znaczenie toposom używanym w ideologicznie nacechowanej argumentacji.

Zgodnie z założeniami KAD i wykorzystywanych przez nią narzędzi retorycznych analizowanie konkretnych tekstów sformalizowanego dyskursu edukacyjnego w zaproponowanym przeze mnie modelu może przebiegać według procedury polegającej na wyznaczaniu makrostrategii, którą w dyskursie edukacyjnym (zgodnie z przyjętym wcześniej założeniem) określić można jako wywieranie nacechowanego ideologicznie wpływu w wymiarze kulturowym, społecznym i politycznym na pokolenie wstępujące przez pokolenie dysponujące środkami władzy i przymusu. Następnie należy wyodrębnić szereg strategii dyskursywnych, przez które realizowana jest owa makrostrategia.

W krytycznej analizie dyskursu strategie dyskursywne traktuje się jako „swego rodzaju schematy, które uwypuklają sposoby, w jakie akty językowe są formowane w dyskursie po to, by osiągnąć pewne strategiczne cele" (Krzyżanowski, 2008: 282), i tak Ruth Wodak wyodrębniła między innymi strategię konstruktywną, służącą konstruowaniu i ustanawianiu pewnych tożsamości, strategię tonowania (wzmacniania), polegającą na zmianie statusu epistemicznego wygłaszanych wypowiedzi ${ }^{18}$

${ }_{18}$ Oznacza to, że tonowanie pewnych wartości lub przekonań przez na przykład przemilczanie ich wybranych aspektów jednocześnie sprawia, że pozostałe wartości i przekonania prezentowane w tekście zostają wyeksponowane i wzmocnione. Podobnie - celowe wzmacnianie ważnych dla nadawcy idei powoduje tonowanie poglądów z jakichś względów uznanych za niewygodne. 
(por. Wodak, 2008: 197) oraz strategię legitymizacji (Krzyżanowski, 2008: 283), uwiarygodniającą władzę polityczną i uzasadniającą prawomocność różnych instytucji poprzez odwołania do tradycji, historii i sytemu wartości podzielanych przez daną grupę społeczną.

Konstruowanie tożsamości kolektywnej młodego pokolenia wymaga istnienia szeregu wzajemnych zależności między strategią konstruktywną a pozostałymi strategiami. Konstruowanie tożsamości wspiera proces legitymizowania władzy lub daje upoważnienie do działania innym podmiotom społecznym, zaś przedstawiciele grupy mającej wpływ na proces powszechnej skolaryzacji profilują znaczenia przedstawiane $\mathrm{w}$ sformalizowanym dyskursie edukacyjnym i ustalają jednakowy dla całego pokolenia paradygmat kulturowy, który obejmuje zarówno wzory myślenia, jak i zespół przekonań oraz hierarchię wartości. Ukształtowany w ten sposób kolektywny osąd rzeczywistości ma jednocześnie sprzyjać uzyskaniu aprobaty dla dotyczących całego społeczeństwa decyzji władz. Elity rządzące wybierają spośród rozmaitych wariantów znaczeń i organizują treść semantyczną pojęć w odniesieniu do wybranych tradycji i systemów wartości. Tym samym dokonują tonowania tego, co w danym znaczeniu jest niepożądane, jednocześnie wzmacniając użyteczny dla siebie sposób definiowania rzeczywistości.

\section{Konkluzja}

Przedstawiona $\mathrm{w}$ artykule koncepcja postrzegania i badania dyskursu edukacyjnego jest jednym z wielu możliwych podejść, zwłaszcza że skupia się ona wyłącznie na szczególnym aspekcie edukacji - sformalizowanym i ujętym w ramy powszechnej i obowiązkowej skolaryzacji. Takie ujęcie nie oznacza wcale, że szkoła poddana jest wyłącznie wpływom ideologii politycznych. Bona fide wprowadza się do niej szereg ideologii kulturowych i społecznych (w tym również pedagogicznych), które nie kojarzą się wprawdzie z polityką, ale także dążą do konstruowania pewnego założonego z góry modelu tożsamościowego - nawet jeśli jego celem jest wychowanie do samostanowienia i wolności. Metody przyjęte do badania sformalizowanego dyskursu edukacyjnego mogą zatem pomóc w określeniu makrostrategii, strategii i realizujących je struktur argumentacyjnych, które (często nieświadomie) wykorzystuje się także do profilowania sądów o rzeczywistości w szerzej pojętej edukacji. Nawet jeśli założy się, że jest to edukacja, w której do minimum ograniczono, czy nawet zniesiono przymus, to jednak wywierany przez nią wpływ bazuje na aspekcie poznawczym (ideologicznym), który jest immanentnym składnikiem każdego typu dyskursu właściwego dla rozmaitych praktyk społecznych. 


\section{Literatura}

Barthes R. (1977). Analiza retoryczna, przeł. K. Falicka. „Pamiętnik Literacki” z. 2.

Bartmiński J. (2010). Pojęcie językowego obrazu świata i sposoby jego operacjonalizacji (tekst w druku). cyt. za: Czachur W. (2011). Dyskursywny obraz świata. Kilka refleksji. „Tekst i dyskurs - text und diskurs" nr 4.

Bauman Z. (1998). Ideologia. [W:] Encyklopedia socjologii t. 1. Warszawa.

Benveniste É. (1966). Problèmes de linguistique générale. Paris.

Bernstein B. (1990). Odtwarzanie kultury, przeł. Z. Bokszański, A. Piotrowski. Warszawa.

Bourdieu P. (2005). Dystynkcja. Społeczna krytyka władzy sądzenia, przeł. P. Biłos. Warszawa.

Bourdieu P., Passeron J.-C. (1990). Reprodukcja. Elementy teorii systemu nauczania, przeł. E. Neyman. Warszawa.

Charaudeau P. (2001). Langue, discours et identité culturelle. "Etudes de Linguistique Appliquée" No. 123/124. Paris.

Chilton P. (2008). Brakujące ogniwo KAD: moduty, amalgamaty i instynkt krytyczny. [W:] A. Duszak, N. Fairclough (red.). Krytyczna analiza dyskursu. Interdyscyplinarne podejście do komunikacji społecznej, przeł. J. Piotrowski. Kraków.

Czachur W. (2011). Dyskursywny obraz świata. Kilka refleksji. „Tekst i dyskurs - text und diskurs” $\mathrm{nr} 4$.

Dąmbska-Prokop U. (1997). Śladami ttumacza. Częstochowa-Kraków.

Dessons G. (2006). Émile Benveniste: L'invention du discours. Paris.

Dobrzyńska T. (1991). Tekst. Próba syntezy. „Pamiętnik Literacki” z. 2.

Duszak A. (1998). Tekst, dyskurs, komunikacja międzykulturowa. Warszawa.

Evert G. (1993). Habermas i edukacja (wplyw Habermasa na anglosaska literature pedagogiczna).

[W:] Z. Kwieciński (red.). Nieobecne dyskursy. cz. III, przeł. Z. Melosik. Toruń.

Fairclough N., Wodak R. (2006). Krytyczna analiza dyskursu, przeł. A. Ostolski. [W:] A. Jasińska-Kania, L. Nijakowski, J. Szacki, M. Ziółkowski (red.). Współczesne teorie socjologiczne. Warszawa.

Fauconnier G. (1999). Mappings in Thought and Language. Cambridge.

Fleischer M. (1994). Problemy i hipotezy systemowej teorii kultury. Wrocław.

Foucault M. (1966). Les mots et les choses. Une archéologie des sciences humaines. Paris.

Foucault M. (1971). Lordre du discours. Paris.

Foucault M. (1977). Archeologia wiedzy, tłum. A. Siemek. Warszawa.

Gajda S. (1999). Współczesny dyskurs naukowy. [W:] S. Gajda (red.). Dyskurs naukowy - tradycja i zmiana. Opole.

Gajda S. (2001). Nowe społeczności dyskursywne a edukacja komunikacyjna. [W:] J. Bralczyk, K. Osiołek-Kłosińska (red.). Zmiany w publicznych zwyczajach językowych. Warszawa.

Gill A.M., Whedbee K. (2001). Retoryka, przeł. G. Grochowski. [W:] T.A. Van Dijk (red.). Dyskurs jako struktura i proces. Warszawa.

Grabias S. (1994). Język w zachowaniach społecznych. Lublin.

Grzegorczykowa R. (1998). Głos w dyskusji o pojęciu tekstu i dyskursu. [W:] J. Bartmiński, B. Boniecka (red.). Tekst. Problemy teoretyczne. Lublin.

Grzmil-Tylutki H. (2007). Gatunek w świetle francuskiej teorii dyskursu. Kraków.

Guzik B. (2003). Powinnościowy model języka w dyskursie edukacyjnym. Kraków. 
Habermas J. (2004). Działanie komunikacyjne i detranscendentalizacja rozumu, przeł. W. Lipnik. Warszawa.

Hymes D.L. (1980). Socjolingwistyka i etnografia mówienia. [W:] Język i społeczeństwo. Wybrał i wstępem opatrzył M. Głowiński. Warszawa 1980, s. 41-82.

Jastrzębski J. (2011). Ideologia i komunikacja. O edukacji, pedagogice i mediach. Wrocław.

Jaźwiński R. (2008). Historiozoficzne meandry mitu „nowego państwa”(mitu założycielskiego). [W:] B. Szklarski (red.). Mity, symbole i rytuały we współczesnej polityce. Warszawa.

Jeziński M. (2008). O mitotwórczej roli słowa w dyskursie politycznym. [W:] B. Szklarski (red.). Mity, symbole i rytuały we wspótczesnej polityce. Warszawa.

Kawka M. (1999). Dyskurs szkolny. Zagadnienia języka. Kraków.

Krakowiak T. (2008). Analiza dyskursu - próba nakreślenia pola badawczego. [W:] A. Horolets (red.). Analiza dyskursu w socjologii i dla socjologii. Toruń.

Kress G. (1985). Linguistic Process in Sociocultural Practice. Oxford.

Kurcz I. (1992). Język a psychologia. Warszawa.

Kurczab H. (1999). Dyskurs edukacyjny. [W:] Z. Budrewicz, M. Jędrychowska (red.). Z uczniem pośrodku. Podmiotowa dydaktyka literatury, języka, kultury. Kraków.

Labocha J. (1996a). Tekst, wypowiedź, dyskurs. [W:] S. Gajda, M. Balowski (red.). Styl a tekst. Opole.

Labocha J. (1996b). Dyskurs jako proces przekazywania wiedzy. [W:] T. Rittel, J. Ożdżyński (red.). Dyskurs edukacyjny. Kraków.

Langacker R. (1995). Wykłady z gramatyki kognitywnej. Lublin.

Libura A. (2006). Przestrzenie mentalne w dyskursie poetyckim. [W:] G. Habrajska, J. Ślósarska (red.). Kognitywizm w poetyce i stylistyce. Kraków.

Lichański J.Z. (2007). Dzieje polskiej retoryki i myśli retorycznej: ocena stanu badań, określenie perspektyw badawczych i próba oceny miejsca polskiej refleksji nad retoryka w perspektywie komparatystycznej. [W:] B. Sobczak, H. Zgółkowa, (red.). Perspektywy polskiej retoryki. Poznań.

Lisowska-Magdziarz M. (2006). Analiza tekstu w dyskursie medialnym. Kraków.

Meighan R. (1993). Socjologia edukacji, przeł. E. Kiszkurno-Koziej. Toruń.

Nocoń J. (2009). Podręcznik szkolny w dyskursie dydaktycznym - tradycja i zmiana. Opole.

Numan D. (1993). Introducing Discours Analysis. London.

Pêcheux M. (1988). Discourse - structure or event. [W:] C. Nelson, L. Grossberg (red.). Marxism and the Interpretation of Culture. London.

Perelman Ch. (1995). Nowa retoryka i wartości, przeł. T. Pajor. [W:] J. Z. Lichański (red.). O retoryce. Wybrane zagadnienia $z$ teorii literatury. Warszawa.

Puzynina J. (2008). Ideologia w języku polskim. [W:] I. Kamińska-Szmaj, T. Piekot, M. Poprawa (red.). Ideologie w stowach i obrazach. Wrocław.

Ricoeur P. (1989). Język, tekst, interpretacja. Wybór pism, przeł. P. Graff, K. Rosner. Warszawa.

Rittel T. (1996). Słowo $w$ dyskursie edukacyjnym na temat wartości, [w:] T. Rittel (red.) Dyskurs edukacyjny. Kraków.

Rittel T., Rittel S.J. (2015). Dyskurs edukacyjny. Zagadnienia - znaczenia - terminy. Wybór i opracowanie. Kraków.

Rypel A. (2012). Ideologiczny wymiar dyskursu edukacyjnego. Na przykładzie podręczników języka polskiego $z$ lat 1918-2010. Bydgoszcz.

Schulz R. (2003). Wykłady z pedagogiki ogólnej. Perspektywy światopogladowe w wychowaniu t. 1. Toruń.

Skowronek B. (1999). O dialogu na lekcjach w szkole średniej. Analiza pragmatyczno-językowa. Kraków. 
Skudrzyk A. (2005). Czy zmierzch kultury pisma? O synestezji i analfabetyzmie funkcjonalnym. Katowice.

Szacki J. (1991). Ideologia. [W:] A. Kłoskowska (red.). Encyklopedia kultury polskiej XX wieku. Pojęcia i problemy wiedzy o kulturze. Wrocław.

Tillmann K.-J. (1996). Teorie socjalizacji. Społeczność, instytucja, upodmiotowienie, przeł. G. Bluszcz, B. Miracki. Warszawa.

Van Dijk T.A. (2001). Badania nad dyskursem. [W:] T.A. Van Dijk (red.). Dyskurs jako struktura i proces, przel. G. Grochowski. Warszawa.

Wiśniewska H. (2005). Dyskurs edukacyjny jako neologizm w nauczaniu integrującym. [W:] E. Kozak-Czyżewska, D. Dybel, B. Kepa (red.). Współczesne tendencje rozwoju pedagogiki wczesnoszkolnej. Kielce.

Witkowska M. (2004). Dyslingwistyczna definicja dyskursu. „Dialogi Polityczne” nr 3-4.

Wodak R. (2008). Dyskurs populistyczny: retoryka wykluczenia a gatunki jezzyka pisanego. [W:] A. Duszak, N. Fairclough, (red.). Krytyczna analiza dyskursu. Interdyscyplinarne podejście do komunikacji społecznej. przeł. J. Wawrzyniak, A. Wójcicki. Kraków.

Wodak R., Koller V. (red.). (2008). Handbook of Communication in the Public Sphere. Berlin.

Wodak R., Krzyżanowski M. (red.). (2011). Jakościowa analiza dyskursu w naukach społecznych. Warszawa.

Zając M. (1996). Niektóre psychologiczne aspekty badań nad dyskursem edukacyjnym. [W:] T. Rittel (red.). Dyskurs edukacyjny. Kraków.

Zawadowski L. (1966). Lingwistyczna teoria języka. Warszawa.

Ziomek J. (1986). O współczesności retoryki. [W:] J. Sławiński (red.). Teoretycznoliterackie tematy i problemy. Wrocław-Warszawa-Kraków-Gdańsk-Łódź.

Żydek-Bednarczuk U. (2005). Wprowadzenie do lingwistycznej analizy tekstu. Kraków.

Żydek-Bednarczuk U., Zeler B. (1996). Strategia i komunikacja w dyskursie edukacyjnym. [W:] T. Rittel, J. Ożdżyński (red.). Dyskurs edukacyjny. Kraków. 